\title{
PENGARUH DUKUNGAN SOSIAL TEMAN SEBAYA DAN REGULASI DIRI TERHADAP PENYESUAIAN DIRI SANTRI
}

\author{
Mia Apriani dan Zulfa Indira Wahyuni \\ Univesitas Islam Negeri (UIN) Syarif Hidayatullah Jakarta \\ E-mail: zulfaindirawahyuni@gmail.com
}

\begin{abstract}
Abstrak: Penelitian ini bertujuan untuk mengetahui pengaruh dukungan sosial teman sebaya (emotional attachment, social integration, reassurance of worth, reliable alliance, guidance, opportunity to provide nurturance) dan regulasi diri terhadap penyesuaian diri santri baru di pondok pesantren. Subjek penelitian ini adalah santri kelas 1 MTs Pondok Pesantren Darus-Salam dan Darut-Taqwa yang berjumlah 196 orang santri, diambil dengan teknik non probability sampling. Uji validitas alat ukur menggunakan teknik confirmatory factor analysis (CFA), dan analisis data menggunakan teknik analisis regresi berganda. Hasil penelitian menunjukkan bahwa terdapat pengaruh signifikan antara dukungan sosial teman sebaya (emotional attachment, social integration, reassurance of worth, reliable alliance, guidance, opportunity to provide nurturance) dan regulasi diri terhadap penyesuaian diri santri baru di Pondok Pesantren sebesar 56.1\%. Hasil penelitian juga menunjukkan bahwa ada penyesuaian diri pada santri perempuan lebih baik daripada penyesuaian diri pada santri laki-laki.
\end{abstract}

Kata Kunci: dukungan sosial teman sebaya, regulasi diri, penyesuaian diri

\section{PENDAHULUAN}

Pesantren merupakan suatu tempat pendidikan dan pengajaran yang menekankan pelajaran agama Islam dan didukung asrama sebagai tempat tinggal santri yang bersifat permanen (Qomar, dalam Hidayat, 2012). Zamakhsyari Dhofier dalam Tradisi Pondok Pesantren mendefinisikan pesantren sebagai lembaga pendidikan tradisional Islam untuk mempelajari, memahami, menghayati dan mengamalkan ajaran Islam dengan menekankan pentingnya moral keagamaan sebagai pedoman perilaku sehari-hari (Dhofier, 2015). Lingkungan ini memiliki karakteristik yang berbeda dengan kondisi lingkungan rumah santri sebelumnya. Santri atau sebutan bagi murid yang belajar dan menuntut ilmu agama di pondok pesantren akan menemui banyak hal baru.

Santri harus bertemu dan bergaul dengan orang-orang yang belum pernah dikenal sebelumnya dengan watak, kebudayaan, status sosial dan kebiasaan yang berbeda-beda. Sementara itu santri juga dituntut untuk hidup mandiri terpisah dari orang tua. Kehidupan di Pondok Pesantren yang sangat berbeda dengan kehidupan santri sebelumnya membuat mereka harus melakukan penyesuaian diri agar dapat bertahan, sehingga mampu menuntut ilmu secara optimal dan menyelesaikan pendidikannya di pondok pesantren tersebut.

Lingkungan pondok pesantren mengajarkan santri untuk hidup mandiri, disiplin, serta menekankan kesederhanaan. Di dalam pesantren santri disuguhkan dengan berbagai aturan dan batasan. Setiap hari santri diatur oleh kegiatan-kegiatan yang tidak ringan, mulai dari bangun tidur hingga tidur kembali diatur sedemikian rupa sehingga tidak ada waktu yang terbuang percuma. Kegiatan yang ditetapkan di pesantren terkadang membuat santri tidak bisa beradaptasi dengan baik. Santri 


\section{1 - 171 | HARKAT: Media Komunikasi Islam Tentang Gender dan Anak, 11 (2), 2015}

diwajibkan mengikuti peraturan yang telah ditetapkan. Jika santri tidak bisa mengikuti peraturan yang ada, maka santri akan mendapatkan hukuman sesuai dengan pelanggaran yang dilakukan.

Bagi santri baru yang duduk di tingkat pertama, ketika mereka baru memasuki lingkungan yang baru, dibutuhkan kemampuan penyesuaian diri yang baik. Padatnya jadwal yang diterima para santri kemudian memberi dampak lain pada kehidupannya. Mulai dari jam tidur yang kurang, jadwal yang penuh, makan apa adanya, pelajaran yang berbeda dari SMP umum, pelajaran agama yang banyak, hafalan-hafalan, bahkan santri juga kurang waktu untuk istirahat dan bersantai. Banyak santri yang tidak mampu menyesuaikan diri dengan kehidupan lingkungan pesantren tersebut. Tak jarang santri yang keluar dari Pondok sebelum lulus atau bahkan pada tahun pertama di Pondok Pesantren.

Penyesuaian diri (self adjustment) merupakan usaha individu untuk menyesuaikan diri dengan lingkungan tempat ia tinggal. Selama hidupnya manusia selalu dituntut untuk menyesuaikan diri dengan lingkungannya. Menurut Haber dan Runyon (dalam Ahmad \& Zadeh, 2014), penyesuaian diri adalah kemampuan individu untuk memiliki persepsi yang akurat terhadap realitas, kemampuan untuk mengatasi stres dan kecemasan, gambaran diri yang positif, kemampuan mengekspresikan berbagai perasaan dan memiliki hubungan interpersonal yang baik.

Hasil penelitian Yuniar, Zaenal dan Tri Puji (dalam Hidayat, 2012) menunjukkan bahwa setiap tahunnya $5-10 \%$ dari santri baru di Pondok Pesantren Modern Islam (PPMI) Assalam Surakarta mengalami masalah dalam melakukan proses penyesuaian diri, seperti: tidak mampu mengikuti pelajaran, tidak bisa tinggal di asrama karena tidak bisa hidup terpisah dengan orang tua, melakukan tindakan-tindakan yang melanggar aturan Pondok Pesantren dan sebagainya.

Selain itu, berdasarkan hasil penelitian Zakiyah, Hidayati, dan Setyawan (2010) di Sekolah Berasrama SMPN 3 Peterongan, terdapat $2.06 \%$ siswa kelas 1 SMP yang tidak mampu menyesuaikan diri dengan kondisi lingkungannya. Mereka merasa mendapakan tekanan yang menyebabkan stress dan siswa cenderung melakukan aktivitas yang lebih menyenangkan, seperti bersantai, tidur-tiduran, bercanda dengan teman atau membaca hal-hal yang lebih santai. Selanjutnya, hasil penelitian Sugiyanto (dalam Alawiyah, 2014) menunjukkan bahwa sebanyak 42,61\% siswa SMP Negeri 15 Bandung mengalami kesulitan dalam penyesuaian sosial. Hal ini diindikasikan dengan rendahnya minat siswa untuk terlibat dalam kegiatan sekolah tanpa alasan, membolos, dan nongkrong pada jam pelajaran.

Pada penelitian Alawiyah (2014) di Pondok Pesantren Assa'adah ditemukan pula masalah mengenai kurangnya penyesuaian diri di pondok pesantren, yaitu santri yang keluar dari pondok pesantren sebelum kelulusan. Beberapa santri mengaku tidak betah di lingkungan pondok pesantren yang mengikat dengan berbagai peraturan. Selain itu, hasil wawancara dengan pengasuh Pondok Pesantren Assa'adah bahwa setiap tahun ajaran baru Pondok Assa'adah selalu kelimpahan santri baru, sampai kekurangan tempat. Namun, tidak semua santri baru betah dan bertahan sampai lulus. Pada tahun Ajaran 2011/2012 penerimaan santri baru mencapai 120 orang dan tiga bulan sampai enam bulan santri yang keluar 20 orang, adapun pada tahun ajaran 2012/2013 penerimaan santri baru adalah 110 orang dan enam bulan kemudian sekitar 18 orang keluar. Salah satu alasan santri yang keluar adalah karena ketidakmampuannya dalam menyesuaikan diri di lingkungan pesantren dengan berbagai peraturan yang ketat. 
Tallent (dalam Rohmah, 2004) mengatakan bahwa ada individu yang berhasil dalam melakukan penyesuaian diri, tetapi ada juga yang terhambat penyesuaian dirinya. Penyesuaian diri yang baik akan memberikan kepuasan yang lebih besar bagi kehidupan seseorang. Hanya individu yang mempunyai kepribadian kuat yang mampu menyesuaikan diri secara baik. Gejala yang timbul pada seseorang yang mengalami kegagalan dalam menyesuaikan diri, seperti rasa cemas yang berlebihan, murung, depresi, stress, atau gangguan kesehatan lain dapat menghambat seseorang dalam melakukan aktivitas.

Dari beberapa fenomena dan hasil penelitian tersebut, dapat dijelaskan bahwa penyesuaian diri sangat penting untuk remaja. Terutama bagi santri yang baru memasuki tingkat pertama, usia mereka adalah usia periode remaja awal yang merupakan transisi dari masa kanak-kanak menuju masa dewasa (Santrock, 2007). Dengan adanya penyesuaian diri yang baik maka santri dapat beradaptasi dengan semua peraturan yang diterapkan di lingkungan pesantren, mengikuti kegiatan belajar yang baik, mencapai prestasi yang tinggi dan memuaskan, tidak bergantung dengan orang lain, serta dapat membina hubungan yang baik dengan guru dan teman sebayanya.

Banyak sekali faktor yang dapat memengaruhi penyesuaian diri, salah satunya adalah dukungan sosial teman sebaya. Dukungan sosial merupakan hal yang dibutuhkan bagi siapapun dan dalam masa perkembangan apapun. Dukungan sosial dapat berasal dari berbagai sumber seperti pasangan/kekasih, keluarga, teman, terapis, dokter, atau organisasi masyarakat. Dengan adanya dukungan sosial, seseorang akan mampu bertahan dalam hidupnya. Seseorang yang memiliki dukungan sosial percaya bahwa mereka dicintai, dihargai, dan merupakan bagian dari jaringan sosial, seperti keluarga atau organisasi komunitas, yang dapat membantu mereka pada saat dibutuhkan (Sarafino, 2011).

Santri yang menuntut ilmu di Pondok Pesantren dan hidup jauh dari orang tua membutuhkan teman yang dapat membantu dirinya untuk menyesuaikan diri. Teman sebaya (peers) adalah anak-anak atau remaja dengan tingkat usia atau tingkat kedewasaan yang sama. Salah satu fungsi utama kelompok teman sebaya adalah untuk menyediakan berbagai informasi mengenai dunia diluar keluarga. Pada banyak remaja, bagaimana mereka dipandang oleh teman sebaya merupakan aspek yang terpenting dalam kehidupan mereka. Beberapa remaja akan melakukan apapun, agar dapat dimasukkan sebagai anggota (Santrock, 2007).

Dalam perkembangan individu pada masa remaja, kelompok teman sebaya memiliki peran yang sangat penting baik secara emosional maupun secara sosial. Menurut Cutrona dan Russell (dalam Lopez \& Cooper, 2011), dukungan sosial memiliki enam fungsi sosial atau "ketentuan" yang diperoleh dari hubungan dengan orang lain. Hal tersebut dibutuhkan individu untuk merasa cukup didukung oleh orang lain dan untuk menghindari kesepian. Dukungan sosial dari teman sebaya sangat dibutuhkan oleh santri baru untuk saling menasihati, mendukung, saling terbuka, saling menyayangi dan bisa saling kerjasama dalam menyelesaikan berbagai tuntutan di Pondok Pesantren.

Costin dan Jones (dalam Santrock, 2007) menjelaskan bahwa dukungan dari teman sebaya berhubungan erat dengan penyesuaian diri remaja awal yang lebih baik dalam mengatasi proses transisi sekolah pada siswa kelas enam dan siswa kelas Sembilan. Hasil penelitian yang dilakukan Rahma (2011) tentang pengaruh dukungan sosial terhadap penyesuaian diri remaja di panti asuhan menunjukkan bahwa dukungan sosial memberikan kontribusi sebesar $18.1 \%$ terhadap penyesuaian diri. Hal ini 


\section{3-171 | HARKAT: Media Komunikasi Islam Tentang Gender dan Anak, 11 (2), 2015}

menunjukkan bahwa dukungan sosial berpengaruh terhadap penyesuaian diri.

Hilman (dalam Ristianti, 2009) menjelaskan bahwa dukungan dari teman sebaya membuat remaja merasa memiliki teman senasib, teman untuk berbagi minat yang sama, dapat melaksanakan kegiatan kreatif sifatnya, saling menguatkan bahwa mereka dapat berubah ke arah yang lebih baik dan memungkinkan remaja memperoleh rasa nyaman, aman serta rasa memiliki identitas diri. Ia juga mengatakan bahwa dukungan teman sebaya biasanya terjadi dalam interaksi sehari-hari remaja, misalnya melalui hubungan akrab yang dijalin remaja bersama teman sebayanya melalui suatu perkumpulan di kehidupan sosialnya, salah satunya ialah lingkungan sekolah.

Dalam perubahan sosial, santri dituntut untuk mampu mengatasi sebagian besar permasalahan yang timbul sebagai hasil dari interaksi dengan lingkungan sosial dan dapat menyesuaikan diri dengan tuntutan lingkungan. Dalam statusnya sebagai santri, mereka dituntut untuk mematuhi dan mentaati peraturan pesantren yang berlaku. Agar dapat berperilaku sesuai dengan tuntutan pesantren, maka para santri perlu melakukan pengendalian diri dalam berperilaku, dan kemampuan untuk melakukan pengendalian diri dalam berperilaku merupakan salah satu bagian dari kemampuan regulasi diri.

Selain dukungan sosial teman sebaya, regulasi diri juga merupakan salah satu faktor yang dapat mempengaruhi penyesuaian diri remaja. Regulasi diri merupakan kemampuan untuk mengembangkan, melaksanakan, dan mempertahankan perilaku diri dengan fleksibel yang direncanakan untuk mencapai suatu tujuan. (Brown, Miller \& Lawendowski, 1999). Dengan mampu melakukan regulasi diri, maka individu dapat menunjukkan perilaku yang sesuai dengan tuntutan pesantren berhubungan dengan perannya sebagai seorang santri.
Menurut Zimmerman (dalam Boekaerts, Pintrich, \& Zeidner, 2000), regulasi diri dapat dibentuk melalui tiga fase yang bersiklus yaitu fase forethought atau perencanaan, mengacu pada suatu proses yang terjadi sebelum adanya usaha-usaha untuk bertindak. Selanjutnya, fase performance atau volitional control, merupakan proses pelaksanaan dari fase forethought. Kemudian fase self reflection (proses evaluasi), individu akan mengamati dan menyesuaikan perilaku yang telah direncanakannya pada fase forethought serta menilai apakah perilaku yang ditampilkan sesuai dengan harapan yang berasal dari usaha dirinya atau disebabkan oleh pengaruh lingkungan.

Rendahnya penyesuaian diri tidak terlepas dari regulasi diri mereka untuk mengedalikan perilakunya sendiri. Regulasi diri merupakan kemampuan yang membantu kita untuk mengatur respon yang terjadi dalam hidup kita. Apabila santri tidak dapat mengatur perilakunya, maka mereka akan kesulitan dalam penyesuaian diri di pesantren.

Berdasarkan hasil penelitian Zariah (2013) di Pondok Pesantren Modern Surakarta, santri yang mampu mengatur dirinya dengan baik cenderung memiliki kemampuan yang memudahkan santri untuk menyesuaikan diri, sehingga santri dapat menjalani kehidupan di Pondok Pesantren dengan sabar, senang dan ikhlas. Selain itu, Evans (dalam Husna, NRH \& Ariati, 2012) mengatakan bahwa regulasi diri bermanfaat dalam membantu siswa mencapai banyak prestasi di sekolah, termasuk prestasi sosial yang dalam hal ini adalah penyesuaian diri dengan lingkungan sosial. Dengan adanya regulasi diri santri diharapkan dapat semakin mandiri dalam mengelola dirinya sendiri dan menyesuaikan diri dengan lingkungan baru di pesantren. Semakin tinggi regulasi diri seseorang, maka semakin baik pula penyesuaian dirinya.

Berdasarkan uraian tersebut, penulis tertarik untuk melakukan penelitian yang 
berjudul "Pengaruh Dukungan Sosial Teman Sebaya dan Regulasi Diri terhadap Penyesuaian Diri Santri”

Penelitian ini bertujuan untuk memperoleh gambaran dan penjelasan tentang pengaruh signifikan dukungan sosial teman sebaya (emotional attachment, social integration, reassurance of worth, reliable alliance, guidance, opportunity to provide nurturance) dan regulasi diri terhadap penyesuaian diri santri baru di Pondok Pesantren.

\section{Penyesuaian Diri}

Menurut Aggarwal (dalam Salami, 2011) penyesuaian diri merupakan sebuah proses yang berkelanjutan di mana bervariasinya perilaku seseorang untuk menghasilkan hubungan yang lebih harmonis antara dirinya dan lingkungannya. Sedangkan menurut Atwater (dalam Hapsariyanti \& Taganing, 2009), penyesuaian diri adalah suatu perubahan yang dialami seseorang untuk mencapai suatu hubungan yang memuaskan dengan orang lain dan lingkungan di sekitarnya.

Schneiders (dalam Kusdiyati, Halimah, \& Faisaluddin, 2011) mengemukakan bahwa penyesuaian diri merupakan suatu proses yang mencakup respon mental dan tingkah laku, di mana individu berusaha untuk dapat berhasil mengatasi kebutuhan-kebutuhan dalam dirinya, ketegangan-ketegangan, konflik-konflik, dan frustrasi yang dialaminya, sehingga terwujud tingkat keselarasan atau harmoni antara tuntutan dari dalam diri dengan apa yang diharapkan oleh lingkungan di mana ia tinggal.

Haber dan Runyon (dalam Ahmad \& Zadeh, 2014) juga mengemukakan bahwa penyesuaian diri adalah kemampuan individu untuk memiliki persepsi yang akurat terhadap realitas, kemampuan untuk mengatasi stres dan kecemasan, gambaran diri yang positif, kemampuan untuk mengekspresikan berbagai perasaan dan memiliki hubungan interpersonal yang baik.

Menurut Haber dan Runyon (1984), penyesuaian diri yang efektif memiliki lima aspek karakteristik, yaitu:

a. Persepsi yang akurat terhadap realitas, individu mengubah persepsinya tentang kenyataan hidup dan menginterpretasikan suatu kejadian, sehingga individu mampu menentukan tujuan realistis sesuai kemampuannya.

b. Kemampuan mengatasi stres dan kecemasan, individu mampu mengatasi masalah-masalah yang timbul dalam hidup dan mampu menerima kegagalan yang dialami.

c. Gambaran diri yang positif, berkaitan dengan penilaian individu tentang dirinya sendiri baik melalui penilaian pribadi maupun melalui penilaian orang lain, sehingga individu dapat merasakan kenyamanan psikologis.

d. Kemampuan mengekspresikan perasaan dengan baik, individu dapat mengekspresikan emosi dengan baik dan mampu melakukan kontrol emosi yang baik.

e. Memiliki hubungan interpersonal yang baik, berkaitan dengan hakikat individu sebagai makhluk sosial. Individu yang memiliki penyesuaian diri yang baik mampu membentuk hubungan dengan cara yang berkualitas dan bermanfaat satu sama lain.

\section{Dukungan Sosial Teman Sebaya}

Dukungan sosial dapat berasal dari berbagai sumber seperti pasangan/kekasih, keluarga, teman, terapis, dokter, atau organisasi masyarakat. Seseorang yang memiliki dukungan sosial percaya bahwa mereka dicintai, dihargai, dan merupakan bagian dari jaringan sosial, seperti keluarga atau komunitas organisasi, yang dapat membantu mereka pada saat dibutuhkan. (Sarafino, 2011). 


\section{5-171 | HARKAT: Media Komunikasi Islam Tentang Gender dan Anak, 11 (2), 2015}

Cowie dan Wallace (dalam Kusumadewi, Hardjajani, \& Priyatama, 2012) mengungkapkan bahwa dukungan sosial teman sebaya merupakan dukungan sosial yang dibangun dan bersumber dari teman sebaya, mereka secara spontan menawarkan bantuan kepada kawan lainnya, dan hal tersebut dapat terjadi di manapun dan kelompok sebaya manapun, serta bagaimana memberikan dukungan disaat kawan lain dalam kesulitan. Sedangkan menurut Tarakanita (dalam Ristianti, 2009), dukungan sosial yang bersumber dari teman sebaya dapat membuat remaja memiliki kesempatan untuk melakukan berbagai hal yang belum pernah mereka lakukan serta belajar mengambil peran yang baru dalam kehidupannya.

Menurut Cutrona dan Russell (dalam Lopez \& Cooper, 2011), dukungan sosial memiliki enam fungsi sosial atau "ketentuan" yang diperoleh dari hubungan individu dengan orang lain. Hal tersebut dibutuhkan individu untuk merasa cukup didukung oleh orang lain dan untuk menghindari kesepian.

Cutrona dan Russell (dalam Lopez \& Cooper, 2011) membagi dukungan sosial menjadi enam dimensi di mana masing-masing dimensi dapat berdiri sendiri, namun satu sama lain saling berhubungan. Adapun dimensi tersebut antara lain:
a. Emotionnal attachment (merasakan kedekatan emosional dan rasa aman)
b. Social integration (mempunyai kesempatan untuk berbagi minat dan kesenangan melakukan aktivitas bersama dengan kelompok)
c. Reassurance of worth (penghargaan atau pengakuan terhadap keterampilan dan kemampuan yang dimiliki)
d. Reliable alliance (ikatan/hubungan yang dapat diandalkan)

e. Guidance (informasi, saran, atau nasihat yang dibutuhkan)

f. Opportunity to provide nurturance (perasaan dibutuhkan orang lain).

\section{Regulasi Diri}

Regulasi diri secara luas mengacu kepada proses psikologis di mana orang mengontrol pikiran, emosi dan perilaku mereka. (Baumeister, Carver \& Scheier, dalam Hoyle, 2010). Regulasi diri menurut Aspinwall (dalam Coffey Laura, 2012) didefinisikan sebagai sebuah proses yang melibatkan kontrol, arah, dan koreksi tindakan diri sendiri dalam proses menuju atau menjauh dari tujuan.

Cervone dan Pervin (dalam Alfiana, 2013) mengemukakan regulasi diri sebagai motivasi internal, yang berakibat pada timbulnya keinginan seseorang untuk menentukan tujuantujuan dalam hidupnya, merencanakan strategi yang akan digunakan, serta mengevaluasi dan memodifikasi perilaku yang akan dilakukan.

Menurut Brown, Miller dan Lawendowski (1999), Regulasi diri merupakan kemampuan untuk mengembangkan, melaksanakan, dan mempertahankan perilaku diri dengan fleksibel yang direncanakan untuk mencapai suatu tujuan. Tujuan dari regulasi diri adalah untuk memonitor dan menyesuaikan perilaku dalam rangka memenuhi tujuan dan pada tingkat yang lebih umum memenuhi usaha konstan terhadap kesejahteraan (Marques, Ibanez, Ruiperez, Moya, \& Ortet, dalam Hoyle, R.H, 2010).

Brown, Miller dan Lawendowski (1999) memformulasikan regulasi diri menjadi tujuh tahapan, antara lain:

a. Receiving yaitu langkah awal individu dalam menerima informasi dari berbagai sumber.

b. Evaluating, individu menganalisis informasi.

c. Triggering yaitu membuat suatu perubahan. Timbul respon positif atau negatif yang 
menimbulkan kecenderungan kearah perubahan.

d. Searching, individu mencari jalan keluar dari permasalahan yang dihadapi.

e. Formulating yaitu merancang suatu rencana.

f. Implementing yaitu menerapkan rencana, melakukan tindakan yang tepat yang mengarah ke tujuan dan memodifikasi sikap sesuai dengan yang diinginkan.

g. Assessing atau mengukur efektivitas dari rencana yang telah dibuat. Pengukuran ini dilakukan pada tahap akhir.

\section{METODE PENELITIAN}

Variabel yang ada pada penelitian ini adalah penyesuaian diri sebagai variabel terikat kemudian dukungan sosial teman sebaya (emotional attachment, social integration, reassurance of worth, reliable alliance, guidance, opportunity to provide nurturance) dan regulasi diri sebagai variabel bebas. Penelitian ini menggunakan kuesioner berupa skala likert brdasarkan pengembangan teori dari masingmasing variabel. Subjek yang ada dalam penelitian ini adalah santri kelas $1 \mathrm{MT}$ s Pondok Pesantren Darus-Salam dan Darut-Taqwa yang berjumlah 196 orang santri.

Pengambilan sampel diambil dengan teknik non probability sampling menggunakan teknik purposive sampling (berdasarkan kriteria tertentu yang ditetapkan peneliti). Pada penelitian ini kriterianya hanya santri kelas 1 MTs saja.

Penulis menggunakan tiga alat ukur, yaitu skala penyesuaian diri (Psychological Adjustment Scale) dari teori Haber dan Runyon, skala dukungan sosial (The Social Provisions Scale) yang dikembangkan oleh Cutrona dan Russell, dan skala regulasi diri (The Self Regulation Questionnaire) yang dikembangkan oleh Brown,
Miller dan Lawendowski (1999). Metode analisis penelitian ini menggunakan SPSS dan Lisrell.

\section{HASIL DAN PEMBAHASAN}

Hasil uji hipotesis menggunakan teknik analisis regresi berganda adalah sebagai berikut:

\begin{tabular}{ccccc}
\multicolumn{5}{c}{ Tabel 1. R Square } \\
\hline Model & $\mathrm{R}$ & $\begin{array}{c}\mathrm{R} \\
\text { Square }\end{array}$ & $\begin{array}{c}\text { Adjusted } \\
\text { R Square }\end{array}$ & $\begin{array}{c}\text { Std. Error of } \\
\text { the Estimate }\end{array}$ \\
\hline 1 & $.749^{\mathrm{a}}$ & .561 & .545 & 6.20997
\end{tabular}

Predictors: (Constant), ATTACHMENT, SOC_INTEG, ROW, RA, GUIDANCE, OFN, REGULASI_DIRI

Berdasarkan tabel 1 dapat dilihat bahwa perolehan $\mathrm{R}$ square sebesar 0.561 atau $56.1 \%$ artinya proporsi varians dari penyesuaian diri santri yang dijelaskan oleh semua independent variable dalam penelitian adalah sebesar 0,561 atau $\quad 56.1 \%$ sedangkan $\quad 43.9 \%$ sisanya dipengaruhi oleh variabel lain diluar penelitian.

Tabel 2. Anova

\begin{tabular}{lccccc}
\hline \multicolumn{1}{c}{ Model } & $\begin{array}{c}\text { Sum of } \\
\text { Squares }\end{array}$ & Df & $\begin{array}{c}\text { Mean } \\
\text { Square }\end{array}$ & F & Sig. \\
\hline Regression & 9279.963 & 7 & 1325.709 & 34 & 0.0 \\
Residual & & & & .3 & $00^{a}$ \\
Total & & & & 77 & \\
\hline & 7249.988 & 188 & 38.564 & & \\
\hline & 16529.951 & 195 & & & \\
\hline
\end{tabular}

a. Predictors: (Constant), ATTACHMENT, SOC_INTEG, ROW, RA, GUIDANCE, OFN, REGULASI_DIRI

b. Dependent Variable: PENYESUAIAN_DIRI

Jika dilihat dari kolom Sig. pada tabel 2 dapat diketahui bahwa nilai signifikan lebih kecil $(\mathrm{p}<0.05)$, maka dapat diartikan bahwa ada pengaruh yang signifikan dukungan sosial teman sebaya (emotional attachment, social integration, reassurance of worth, reliable alliance, guidance, opportunity to provide nurturance) dan regulasi diri terhadap penyesuaian diri santri.

Jika dilihat dari kolom Sig. pada tabel 2 dapat diketahui bahwa nilai signifikan lebih kecil $(\mathrm{p}<0.05)$, maka dapat diartikan bahwa ada pengaruh yang signifikan dukungan sosial teman sebaya (emotional attachment, social integration, 
reassurance of worth, reliable alliance, guidance, opportunity to provide nurturance) dan regulasi diri terhadap penyesuaian diri santri.

\begin{tabular}{|c|c|c|c|}
\hline \multirow[t]{2}{*}{ Model } & $\begin{array}{c}\text { Unstandardized } \\
\text { Coefficients }\end{array}$ & $\begin{array}{c}\text { Standardized } \\
\text { Coefficient }\end{array}$ & \multirow[t]{2}{*}{ Sig. } \\
\hline & $\mathrm{B}$ & Beta & \\
\hline (Constant) & -7.776 & & 0.098 \\
\hline $\begin{array}{l}\text { Emotional } \\
\text { attachment }\end{array}$ & 0.343 & 0.300 & $0.000^{*}$ \\
\hline $\begin{array}{l}\text { Social } \\
\text { integration }\end{array}$ & -0.019 & -0.021 & 0.690 \\
\hline $\begin{array}{l}\text { Reassurance of } \\
\text { worth }\end{array}$ & 0.080 & 0.074 & 0.186 \\
\hline $\begin{array}{l}\text { Reliable } \\
\text { alliance }\end{array}$ & 0.209 & 0.180 & $0.003^{*}$ \\
\hline Guidance & 0.101 & 0.066 & 0.247 \\
\hline Opportunity & 0.058 & 0.043 & 0.436 \\
\hline $\begin{array}{l}\text { to provide } \\
\text { nurturance }\end{array}$ & & & \\
\hline Regulasi diri & 0.384 & 0.383 & $.000^{*}$ \\
\hline
\end{tabular}

Berdasarkan pada tabel 3 menunjukkan bahwa persamaan regresinya sebagai berikut:

Penyesuaian diri $=-7.776+0.343$ Emotional attachment* - 0.019 Social integration + 0.080 Reassurance of worth + 0.209 Reliable alliance* +0.101 Guidance + 0.058 Opportunity to provide nurturance + 0.384 Regulasi diri*

Ket: Tanda $(*)=$ Variabel Signifikan

Pada tabel 3, signifikan atau tidaknya koefisien regresi yang dihasilkan dapat dilihat dari nilai sig pada kolom paling kanan. Apabila koefisien regresi sig $<0.05$ maka pengaruhnya terhadap penyesuaian diri signifikan. Berdasarkan data pada tabel di atas, nampak bahwa hanya emotional attachment, reliable alliance dan regulasi diri yang signifikan sedangkan yang lainnya tidak signifikan.

Penjelasan dari nilai koefisien regresi yang diperoleh pada masing-masing iv sebagai berikut:

1. Variabel emotional attachment memiliki nilai signifikan sebesar 0,000 . Karena nilai sig. <0,05 maka dapat disimpulkan bahwa hipotesis nihil $\left(\mathrm{H}_{0}\right)$ ditolak. Jadi, dapat dikatakan bahwa terdapat pengaruh yang signifikan emotional attachment dari variabel dukungan sosial teman sebaya terhadap penyesuaian diri santri. Selain itu, nilai koefisien regresi pada variabel ini bernilai positif. Artinya semakin tinggi nilai emotional attachment maka nilai penyesuaian diri akan semakin tinggi, begitu pula sebaliknya.

2. Variabel social integration memiliki nilai signifikan sebesar 0,690. Karena nilai sig. $<0,05$ maka dapat disimpulkan bahwa hipotesis nihil $\left(\mathrm{H}_{0}\right)$ diterima. Jadi, dapat dikatakan bahwa tidak terdapat pengaruh yang signifikan social integration dari variabel dukungan sosial teman sebaya terhadap penyesuaian diri santri.

3. Variabel reassurance of worth memiliki nilai signifikan sebesar 0,186. Karena nilai sig.>0,05 maka dapat disimpulkan bahwa hipotesis nihil $\left(\mathrm{H}_{0}\right)$ diterima. Jadi, dapat dikatakan bahwa tidak terdapat pengaruh yang signifikan reassurance of worth dari variabel dukungan sosial teman sebaya terhadap penyesuaian diri santri.

4. Variabel reliable alliance memiliki nilai signifikan sebesar 0,003 . Karena nilai sig. $<0,05$ maka dapat disimpulkan bahwa hipotesis nihil $\left(\mathrm{H}_{0}\right)$ ditolak. Jadi, dapat dikatakan bahwa terdapat pengaruh yang signifikan reliable alliance dari variabel dukungan sosial teman sebaya terhadap penyesuaian diri santri. Selain itu, nilai koefisien regresi pada variabel ini bernilai positif. Artinya semakin tinggi nilai reliable alliance maka nilai penyesuaian diri akan semakin tinggi, begitu pula sebaliknya.

5. Variabel guidance memiliki nilai signifikan sebesar 0,247. Karena nilai sig.>0,05 maka dapat disimpulkan bahwa hipotesis nihil $\left(\mathrm{H}_{0}\right)$ diterima. Jadi, dapat dikatakan bahwa tidak terdapat pengaruh yang signifikan guidance dari variabel dukungan sosial 
teman sebaya terhadap penyesuaian diri santri.

6. Variabel opportunity to provide nurturance memiliki nilai signifikan sebesar 0,436 . Karena nilai sig. $>0,05$ maka dapat disimpulkan bahwa hipotesis nihil $\left(\mathrm{H}_{0}\right)$ diterima. Jadi, dapat dikatakan bahwa tidak terdapat pengaruh yang signifikan Opportunity to provide nurturance dari variabel dukungan sosial teman sebaya terhadap penyesuaian diri santri.

7. Variabel regulasi diri memiliki nilai signifikan sebesar 0,000. Karena nilai sig.<0,05 maka dapat disimpulkan bahwa hipotesis nihil $\left(\mathrm{H}_{0}\right)$ ditolak. Jadi, dapat dikatakan bahwa terdapat pengaruh yang signifikan regulasi diri terhadap penyesuaian diri santri. Selain itu, nilai koefisien regresi pada variabel ini bernilai positif. Artinya semakin tinggi nilai regulasi diri maka nilai penyesuaian diri akan semakin tinggi, begitu pula sebaliknya.

8. Pada bahasan sebelumnya, dapat diketahui bahwa terdapat tiga IV yang memiliki pengaruh signfikan terhadap penyesuaian diri, yaitu emotional attachment, reliable alliance dan regulasi diri.

Berdasarkan data pada tabel 3 dapat diketahui bahwa urutan prediktor yang memiliki kontribusi terhadap penyesuaian diri dari yang terbesar hingga yang terkecil adalah regulasi diri dengan kontribusi 0.383 , emotional attachment dengan kontribusi 0.300 , dan reliable alliance dengan kontribusi 0.180 .

Berdasarkan hasil analisis penelitian ditinjau dari jenis kelamin, terdapat perbedaan penyesuaian diri antara santri laki-laki dan santri perempuan. Nilai mean penyesuaian diri pada santri laki-laki sebesar 48.9076 (81 santri) dan nilai mean penyesuaian diri pada santri perempuan sebesar 50,7694 (115 santri). Sehingga dapat disimpulkan bahwa penyesuaian diri pada santri perempuan lebih baik daripada santri laki-laki. Hal ini sesuai dengan teori yang dikemukakan Hawari (dalam Hidayat, 2012) bahwa perempuan mempunyai kemampuan penyesuaian diri yang lebih baik daripada lakilaki. Selain itu, pada hakikatnya perempuan lebih bersifat heterosentris dan lebih sosial, karena itu lebih ditonjolkan sifat sosialnya (Kartono, dalam Hidayat, 2012).

\section{PENUTUP}

\section{Simpulan}

Berdasarkan hasil analisis data serta pengujian hipotesis menggunakan perhitungan Anova yang telah dikemukakan pada data sebelumnya, maka kesimpulan yang dapat diambil dari penelitian ini adalah :

1. Ada pengaruh signifikan dukungan sosial teman sebaya (emotional attachment, social integration, reassurance of worth, reliable alliance, guidance, opportunity to provide nurturance) dan regulasi diri terhadap penyesuaian diri santri baru di pondok pesantren sebesar $56.1 \%$.

2. Terdapat tiga variabel yang berpengaruh signifikan terhadap penyesuaian diri santri baru, yaitu emotional attachment, reliable alliance dan regulasi diri.

3. Dari ketiga IV tersebut yaitu emotional attachment, reliable alliance dan regulasi diri, yang memiliki kontribusi paling besar terhadap penyesuaian diri adalah regulasi diri, memberikan pengaruh beta $(\beta)$ sebesar 0.383 dengan signifikansi 0.000 .

4. Ada perbedaan penyesuaian diri yang ditinjau dari jenis kelamin. Penyesuaian diri pada santri perempuan lebih baik daripada penyesuaian diri pada santri laki-laki. 


\section{Saran}

Dalam penulisan penelitian ini, peneliti menyadari bahwa masih terdapat banyak kekurangan dan keterbatasan. Untuk itu, peneliti memberikan beberapa saran sebagai bahan pertimbangan untuk dapat melengkapi penelitian selanjutnya.

\section{Saran teoritis}

Bagi peneliti lain yang tertarik meneliti variabel dependen yang sama, pemilihan alat ukur penyesuaian diri lainnya disarankan agar memperkaya penelitian di bidang penyesuaian diri. Selain itu penelitian faktor-faktor lain yang dapat memengaruhi penyesuaian diri di luar penelitian ini sangat disarankan seperti keadaan fisik, realisasi diri, kematangan emosi, lingkungan rumah, dan variabel-variabel lainnya. Dengan mempertimbangkan variabel-variabel tersebut, diharapkan penelitian selanjutnya akan lebih menyempurnakan hasil penelitian sebelumnya.

Bagi penelitian selanjutnya, disarankan dapat melakukan penelitian dengan subjek yang bukan hanya berasal dari tingkat SMP dan kelas VII saja, tetapi dapat dari tingkat SMA dan perguruan tinggi pula, sehingga hasil penelitian dapat digeneralisasikan pada populasi yang lebih luas dan diperoleh hasil penelitian yang lebih beragam dan komprehensif.

Bagi peneliti selanjutnya, diharapkan dapat memetakan instrumen penelitian yang digunakan untuk penelitiannya guna memperbaiki hasil penelitian sebelumnya dan mendapatkan hasil penelitian yang lebih baik.

\section{Saran praktis}

Bagi pihak pesantren, disarankan dapat memperbanyak sarana interaksi antar santri selain ekstrakulikuler, misalnya dengan mengadakan kegiatan di luar pondok pesantren secara berkala, selanjutnya melibatkan para santri untuk mengikuti berbagai kegiatan yang ada di masyarakat sekitar pondok pesantren. Hal ini sangat diperlukan, karena melalui kegiatan tersebut santri bersama teman-temannya dapat saling bertukar informasi, memberikan perhatian dan saling memberikan dukungan sosial satu sama lain yang pada akhirnya dapat membantu dalam proses mengembangkan dan mengoptimalkan penyesuaian diri pada masingmasing santri.

Bagi orangtua, diharapkan dapat memberikan perhatian serta pendampingan di tahun-tahun pertama santri masuk pesantren. Selain itu, diharapkan agar orangtua tidak memaksakan anak agar masuk pesantren jika anaknya tidak menginginkannya.

Bagi subjek penelitian, Santri yang telah dapat menyesuaikan diri dengan baik di pesantren diharapkan dapat terus mempertahankan kemampuannya dalam melakukan penyesuaian diri dan bagi santri yang masih belum dapat menyesuaikan diri diharapkan dapat terus meningkatkan kemampuannya dalam penyesuaian diri.

Santri disarankan untuk lebih mengakrabkan diri dan mempererat intensitas pertemanan guna pencapaian penyesuaian diri yang baik.

Untuk emotional attachment, santri diharapkan dapat saling memberikan perhatian dan kasih sayang sesama teman agar dapat menjalankan kegiatan yang ada di pesantren dengan penuh keyakinan dalam diri, serta menunjang kepercayaan diri santri untuk dapat menyesuaikan diri dengan baik di pesantren.

Untuk reliable alliance, santri diharapkan dapat saling memberikan bantuan yang nyata, baik berupa pertolongan, pemberian makanan, tindakan atau materi. Dengan begitu, santri menyadari ada orang yang dapat diandalkan untuk menolongnya bila ia menghadapi masalah dan kesulitan di pesantren. Hal tersebut 
membantu santri untuk dapat menyesuaikan dirinya di lingkungan pesantren.

Santri diharapkan dapat lebih meningkatkan regulasi dirinya agar memiliki penyesuaian diri yang lebih baik lagi.

\section{DAFTAR PUSTAKA}

Ahmad, K.B., \& Zadeh, Z.F. (2014). Gender discrimination in disabled adolescents: An analysis of psychological adjustment in a cosmopolitan city in pakistan. Sociology and Anthropology, 2(6), 232-238.

Alawiyah, I.T.A. (2014). Program bimbingan pribadi-sosial untuk mengembangkan penyesuaian diri santri. Universitas Pendidikan Indonesia.

Alfiana, A. D. (2013). Regulasi diri mahasiswa ditinjau dari keikutsertaan dalam organisasi kemahasiswaan. Jurnal Ilmiah Psikologi Terapan, 1(2).

Boekaerts, M., Pintrich, P. R., \& Zeidner, M. (Eds.) (2000). Handbook of selfregulation. San Diego: Academic Press.

Brown, J. M., Miller, W. R., \& Lawendowski, L. A. (1999). The self-regulation questionnaire. In L. Vandecreek \& T. L. Jackson (Eds.), Innovations in clinical practice: A source book. Sarasota, FL: Professional Resources Press.

Coffey, Laura. (2012). Goals, Adaptive SelfRegulation, and Psychosocial Adjustment to Lower Limb Amputation: A Longitudinal Study. School of Nursing and Human Sciences, Dublin City University, Ireland. 48.

Dhofier, Zamakhsyari. (1982). Tradisi pesantren: Studi tentang pandangan kyai. Jakarta: LP3ES. Diunduh pada tanggal 5 Oktober 2015 dari http://hakamabb as.blogspot.co.id/2013/12/pengertian- pesantren.html

Hapsariyanti, D., \& Taganing, N. M. (2009). Kecerdasan emosi dan penyesuaian diri dalam perkawinan. Jurnal Psikologi Gunadarma, 2(2).

Haber, A., \& Runyon, R. (1984). Psychology of adjustment. Illinois: The Dorsey Press.

Hidayat, D. A. J. (2012). Perbedaan penyesuaian diri santri di pondok pesantren tradisional dan modern. Talenta Psikologi, 1(2).

Hoyle, R. H. (2010). Handbook of personality and self-regulation. Singapore: WileyBlackwell.

Husna, A. N., NRH, Frieda., \& Ariati, J (2012). Regulasi diri mahasiswa berprestasi. Semarang: Universitas Diponegoro.

Kusdiyati, S., Halimah, L., \& Faisaluddin. (2011). Penyesuaian diri di lingkungan sekolah pada siswa kelas XI SMA Pasundan 2 Bandung. Fakultas Psikologi Universitas Islam Bandung, 8(2).

Kusumadewi, S., Hardjajani, T., \& Priyatama, A. N. (2012). Hubungan antara dukungan sosial peer group dan kontrol diri dengan kepatuhan terhadap peraturan pada remaja putri Pondok Pesantren Modern Islam AsSalaam Sukoharjo. Fakultas Kedokteran Universitas Sebelas Maret.

Lopez, M.L., \& Cooper, L. (2011). Social support measures review. Laytonsville: National Center for Latino Child \& Family Research.

Rahma, A. N. (2011). Hubungan efikasi diri dan dukungan sosial terhadap penyesuaian diri remaja di panti asuhan. Yogyakarta: Jurnal Psikologi Islam Universitas Gadjah Mada . 8(2), 231-246.

Ristianti, A. (2009). Hubungan antara dukungan sosial teman sebaya dengan identitas diri pada remaja di SMA Pusaka 1 Jakarta. 
Jurnal Fakultas Psikologi Gunadarma.

Rohmah, F. A. (2004). Pengaruh pelatihan harga diri terhadap penyesuaian diri pada remaja. Indonesian Psychological Journal. 1(1): 53-63.

Salami, S.O. (2011). Psychosocial predictor of adjustment among first year college of education student. Us-China Education Review, 8 (2).

Santrock, J.W. (2005). Adolescence. New York: McGraw-Hill.

Sarafino, E.P., \& Smith, T.W. (2011). Health psychology: Biopsychosocial interactions, (seventh edition). New York : John Willy $\&$ Sons, Inc.
Sarafino, E.P., \& Smith, T.W. (2011). Health psychology: Biopsychosocial interactions, (seventh edition). New York : John Willy $\&$ Sons, Inc.

Zakiyah, N., Hidayati, F.N.R., \& Setyawan, Imam (2010). Hubungan antara penyesuaian diri dengan prokastinasi akademik siswa sekolah berasrama SMPN 3 Jombang. Jurnal Psikologi Undip, 8(2).

Zariah, Ainun. (2013). Pembelajaran regulasi diri pada santri di Pondok Pesantren Modern Surakarta. Surakarta: Fakultas psikologi Universitas Muhammadiyah. 